\title{
Transforming Chinese enterprises: ideology, efficiency and instrumentalism in the process of reform
}

Chao Xi

Historically, the roots of the contemporary Chinese legal system are deeply embedded in the Soviet Union model of the socialist legal system (see Butler 1983). Even today, the Soviet influence can easily be identified, largely reflected in China's constitutional organisation, which replicates to a significant extent that of the former USSR (especially in its 1936 Constitution) (A.H.Y. Chen 2000). This significance, however, has been fading. The economic reforms carried out in the 1980s in China were apparently much more dramatic and liberal than those occurring in the Soviet Union at that time-particularly in terms of development of the non-public sector in the economy and the rapid expansion of foreign investment in, and foreign trade with, China. Soviet legal models were not adequate for China's attempt to create 'socialism with Chinese characteristics'. An increasing number of civil and common law legal doctrines and institutions have found their way into recent Chinese legislation and exert ever-increasing external influences on Chinese legal development.

It may be wrong, however, to conclude that the diminishing influence of the Soviet legal system indicates that socialist ideology will play no part in shaping the future of the Chinese legal system. Indeed, in an attempt to construct a new theory of law, upon which Chinese legal development is based, Chinese jurists have successfully discarded the rigid Vyshinsky-type socialist theory of law (Lo 1997). They have not, however, ventured further to challenge the official socialist ideology of Deng Xiaoping's 'four cardinal principles', which sets the boundaries of legal development in China. In the final analysis, China is one of the few countries in the world that still upholds socialism as an ideological pursuit. So long as China remains a socialist country, socialism will continue to play a substantial role in shaping law and law-related institutions in China. The question to be answered is what role does socialism play? 
This chapter attempts to present an answer to this question by examining the development of Chinese enterprise law, particulary in terms of enterprise/corporate governance. Having officially abandoned the centrally-planned economy, China is now embracing a 'socialist market economy'. As part of the economic reform, stateowned enterprises (SOEs) - the basic unit implementing production plans and providing social welfare in the centrally-planned economy-are gradually being transformed into modern companies, the dominant vehicle for conducting business in the market economy. The prevalent legal instrumentalism has resulted in the development of Chinese enterprise law, in particular its governance aspects, embodying the intricate interactions between socialist ideology and economic efficiency in the process of reform. It is therefore of particular relevance to the central question of this chapter. The second part of this chapter places this analysis in context by briefly outlining enterprise reforms since 1978 and their economic and policy impetus. The third part identifies the two fundamental ideological doctrines of socialism in the context of enterprise reforms, namely, predominance of public ownership of the means of production ${ }^{1}$ and leadership of the ruling Communist Party. The chapter then examines how the two socialist doctrines have shaped law and law-related institutions in China and concludes by presenting some thoughts about socialism and the future of Chinese enterprise law.

\section{CHINESE ENTERPRISE REFORMS: A LONG MARCH TOWARD EFFICIENCY}

The subservience of law to policy and the instrumental use of law in China ${ }^{2}$ make an understanding of the Party's policies on enterprise reforms indispensable if one is to comprehend the development of Chinese enterprise law. As the issue of Chinese enterprise reforms is one that has been explored by numerous works in various disciplines, I will present a brief and necessarily simplified account of the evolution of Chinese enterprise reform policies.

\section{Initial conditions of enterprise reforms}

The Communist Party of China (CPC) gained control over Mainland China and established the PRC in 1949. At the outset of socialist rule, private ownership amounted to 90 per cent of the state economy and public ownership was only of nominal significance. When the CPC was attempting to gain control of the country, the foremost task was to expand the magnitude of public ownership in the economy. Rigorous measures were taken to confiscate state-run enterprises owned by the defeated Kuomintang government, the so-called 'bureaucratic-capital', and enterprises and capital owned by 'hostile' entrepreneurs and governments. ${ }^{3}$ The national bourgeois and the private sector were, however, largely left untouched. As a result, a multi-ownership economy, with public ownership controlling economic 'lifelines', took shape. 
The next stage of development (1953-57) followed a debate within China's leadership over economic development strategies. One side of the debate advocated maintaining the existing mixed ownership economy, whereas the other side called for transformation to a socialist economy (Gao Shangquan and Yang Qixian 1999b). Those favouring transformation won the day, and the first 'Five-Year Plan' was launched in 1953 to carry out 'socialist transformation' with Soviet assistance. The process of socialist transformation resulted in the state assuming control over virtually all industrial organisations by 1956 and restructuring them into SOEs governed and operated in a manner similar to those operating within the Soviet model of command planning. ${ }^{4}$

From 1957 to 1965, China's SOEs underwent huge upheavals, propelled by various forms of political movements and readjustments. ${ }^{5}$ The development of SOE policies was terminated abruptly by the onset of the Cultural Revolution in 1966, though restored ten years later.

\section{Enterprise reforms in the transitional period (1978-92)}

A historical shift in CPC policy took place in 1978. In December 1978, the Third Plenary Session of the CPC Central Committee was held. Among many decisions was that of enterprise reform. The policy orientation of initial enterprise reforms (The People's Daily, 24 December 1978) separated state administration from SOE management, which entailed a delegation of managerial autonomy to the SOEs and their management (The People's Daily, 24 December 1978). A variety of measures, including the retention of a proportion of profits and economic accountability, were implemented.

These efforts barely made any improvements, largely because policy priority was given to reforms in the rural sector prior to 1984. Chai's observation that postMao China adopted an incremental approach to economic reform helps to explain why rural reforms took place first. Reforms were first carried out in the sector where resistance was weakest, and then spread to those sectors where the reform measures were more complex and less popular (Chai 1997). Obviously, less political risk was involved in reforming the rural collective economy than reforming the urban command economy and SOEs, as the latter were associated with much more intractable, deep-rooted and politically explosive problems.

Nevertheless, the task of reforming SOEs was undeniably crucial. Despite their overwhelming dominance in China's economy, SOEs suffered chronically from inefficiency and low productivity. A majority were in debt, incurring an everincreasing and staggering amount of losses, and the subsidies to keep them afloat were an intolerable burden on the central government (Wang 1992). On the other hand, the taxation system was poor, and SOE profits formed the primary source of fiscal revenue for the central government (Lin Zhijun 2001). Given the government's dependence on SOEs for revenue, the ever-deteriorating performance of the state sector threatened to drag down the nation's economy. The need for reforms in the SOE sector could no longer be ignored. 
Inspired by the triumph of the reforms in the rural sector, ${ }^{6}$ the Chinese leadership was determined to place SOE reforms at the top of the economic reform agenda, focusing in particular on fostering SOE efficiency. An efficient state sector was set as the ultimate goal of the SOE reforms, reflecting persistence of the ideological notion that socialism (and hence state-led economic activity) is superior to capitalism (Deng Xiaoping 1994:221-3).

The ground-breaking SOE reforms were initiated in 1984. Blaming SOE inefficiency on the state's direct management of SOEs, the CPC's 'Decision on Economic Structure Reform' (CPC Central Committee 1984) proclaimed that ownership and management of SOEs 'should be appropriately separated'. Stateowned enterprises should become independent legal entities, responsible for their own profits and losses (CPC Central Committee 1984). It is worth noting, however, that, while daily managerial autonomy was largely delegated to the SOEs, ownership of SOE property remained with the state and was never intended to be transferred to the enterprises.

In 1988, the CPC adopted a bolder mechanism, the 'contract responsibility system', to divide state administration from SOE management. Enterprise directors signed contracts with their supervisory authorities, setting targets for enterprise performance. Tackling the enterprise inefficiency problems, once thought to be the panacea, resulted, however, in little improvement (Qi Duojun 2003). It seemed all reforms that avoided removing enterprise property from the regime of the monopolised state ownership ran into barriers and failed to provide meaningful autonomy or incentives for enterprise efficiency.

The Chinese leadership's concerns about SOE efficiency led them to search for an alternative approach to enterprise reform. The fact that stock companies serve as a robust engine for the prosperous capitalist economies meant that establishing a similar shareholding system in China was a tantalising option, but ideological obstacles existed. The concept of establishing a shareholding system and issuing stocks to the public was thought to be inconsistent with, even heretical to, socialist public ownership (Qian 1993).

Starting from the mid 1980s, however, Chinese economists, building on a reference by Karl Marx, claimed that this corporate form developed in capitalist countries could also benefit the socialist economy (Wang 1992). The concept received endorsement from Deng, who was in favour of employing some 'capitalist methods' to build socialism (Deng Xiaoping 1994:151-3), and the policy reversal prompted the Chinese government to open a new path to enterprise reform. Vigorous steps were taken towards establishing a shareholding system, including pilot schemes to transform SOEs into so-called shareholding companies and the opening of stock exchanges in Shanghai and Shenzhen.

Related to the shareholding system reform, a far-reaching ideological breakthrough came from the CPC Thirteenth National Congress in 1987, which proclaimed that China was a socialist country still in the first stages of socialism (Zhao Ziyang 1987). At this point, it was thought that public ownership had to 
predominate, but a private sector could contribute production and employment that the state could not. This shift in policy reflected an intention to permit the existence of private ownership as a supplement to state ownership, which continues to play the leading role in the Chinese economy. Released from the stringent ideological restraints imposed on it, a flourishing private sector soon emerged and provided the resources necessary to support the shareholding system.

\section{Corporatisation: enterprise reforms in the socialist market economy}

Following Deng Xiaoping's triumphant tour of south China in late 1992, the CPC's Decisions on Socialist Market Economy System ${ }^{7}$ of 1993 finally cast aside the concept of a planned economy and marked the eventual adoption by the Chinese leadership of a more liberal and market-oriented reform strategy. The orientation of enterprise reform was declared to be establishing a 'modern enterprise system' with public ownership as its mainstay. Instead of accurately defining the vague term 'modern enterprise system',, the 1993 Decisions delineated it as a system that has 'clarified property rights, designated authorities and responsibilities, separated government and enterprise functions, and established scientific management' (section 2).

Two approaches were identified to modernise the inefficient SOE regime. The first approach was 'converting SOE's operational management mechanisms' while leaving their fundamental ownership and organisational structure unaltered. It is indeed a continuation of the conventional line of enterprise reform. The second approach was corporatising SOEs, particularly large and middle-sized SOEs, in a gradual and realistic way (1993 Decisions, section 6). It signalled that the CPC officially endorsed the shareholding system as a useful instrument to reform SOEs, after many years of experiments, as noted above. Indeed, it was this formal endorsement of the shareholding system that accelerated the enactment and promulgation of the first national company law in $1993 .{ }^{9}$ Given that the first approach was simply an improved version of the already failed 'contract responsibility system' (Qi Duojun 2003:28), it is not surprising that policy priority was attached to the second approach-corporatising SOEs. By corporatising SOEs, the Chinese leadership intended to separate government administration from enterprise management, release the state from its unlimited responsibility for SOEs, raise funds to diversify SOE risks, and, consequently, improve enterprise efficiency (1993 Decisions, section 6).

Notwithstanding the backing of the 1993 Decisions, fears about the capitalist attributes of the shareholding system remained and, from time to time, frustrated the CPC's endeavours to corporatise SOEs. More radical ideological breakthroughs took place in 1997. In his report to the CPC National Congress, Jiang Zemin (1997) redefined the public sector of the economy, which included not only state and collectively-owned sectors, but also the state and collectively-owned elements in the sector of mixed ownership. The dominant position of public ownership could be maintained by the state sector controlling (rather than monopolising) major industries and key areas of the national economy. Along this line, Jiang continued 
boldly to assert that the shareholding system is one of the forms of materialising public ownership, as long as the state or a collective holds the controlling share. This controlling position, Jiang maintained, may indeed expand control capacity and eventually bolster the dominant role of public ownership.

This policy determinacy eventually paved the way for the market-oriented corporatisation and ownership diversification, and prompted the enactment of the long-awaited national securities law in $1998 .{ }^{10}$ To date, most large and medium SOEs have corporatised themselves, although the process has not yet been completed. Ownership diversification is taking place in two main forms: listing on domestic and international stock exchanges in the case of larger SOEs, and sales to domestic and foreign investors in the case of small and medium SOEs. ${ }^{11}$

\section{Ideology}

It has been demonstrated above that the main theme of China's enterprise reform policies has been improving enterprise efficiency. This does not, however, end this observation; rather, it poses another question, namely, what has distinguished China's enterprise reforms from those carried out in the former Soviet bloc, which has also been in search of increasing enterprise efficiency? It is submitted that China's adherence to socialism (with Chinese characteristics) when undertaking enterprise reforms may help to explain the divergence of paths to enterprise reforms.

Through various forms of mass privatisation, most Eastern European and former Soviet Union countries attempted to cut their ties with socialism by radically transforming their communist economies into market economies with 'big bang' strategies (see Coffee 1998; Stiglitz 1999). Conversely, while reforming its SOE regime, China has officially proclaimed its constant adherence to socialism. China has never radically departed from the socialist practicalities of the past. Indeed, the top leaders of the Party have used an efficient SOE regime and the market economy merely as a means to bolster public ownership and socialism. For instance, Deng once bluntly stated

...taking advantage of the useful aspects of capitalist countries, including their methods of operation and management, does not mean that we will adopt capitalism. Instead, we use those methods in order to develop the productive forces under socialism. As long as learning from capitalism is regarded as no more than a means to an end, it will not change the structure of socialism or bring China back to capitalism (1995:239).

Nonetheless, it would be wrong to assume that China's top leaders would stringently and rigidly adhere to socialist ideology. On the contrary, as this chapter has illustrated, the Chinese leaders have taken a pragmatic and flexible stance in interpreting the socialist ideology in a bid to accommodate reforms aimed at increasing enterprise efficiency, which they believe will in turn enhance socialism. The interaction and tension between the concerns to increase efficiency and adherence to socialist ideology also help to explain the conventional observation that China's enterprise reforms are a progressive and incremental process, rather than a significant leap forward. 
This ad hoc interaction has a momentous bearing on legal development in China. Western observers have observed that law in China is still conceived as, and still operates as, an instrument to carry out and consolidate institutional (primarily economic) changes according to predetermined policies (see, for example, Epstein 1994). This legal instrumentalism reflects the assertions of Party leaders that the Chinese legal system is but a means to serve and safeguard economic constructions (Xin Chunyun 1999) and that its development must be conducive to economic development (Chen Jianfu 1999). Law, as an instrument, reflects and substantiates Party policies shaping economic development and enterprise reforms, and the latter guides lawmaking and legal enforcement (Zhang Youyu and Wang Shuwen 1989). Given that enterprise reform policies have been the result of interactions between the concerns about efficiency and the pursuit of socialism, the operation of legal instrumentalism renders it perfectly logical for Chinese enterprise law to be shaped by socialism, although enterprise law also serves to foster enterprise efficiency.

Before turning to examine how socialism has shaped the development of enterprise law in China, it is important to identify the socialist doctrines of direct relevance to enterprise law; it may not be as constructive to discuss socialism in the abstract sense.

In his renowned talk in 1979, Deng enunciated that the ideological prerequisite of China's economic reform was the so-called 'four cardinal principles', namely: upholding the leadership of the Communist Party, upholding the socialist road, upholding the dictatorship of the proletariat; and upholding the Marxist-Leninism and Mao Zedong Thought. In 1987, he maintained that, of the four cardinal principles, upholding the leadership of the Party and upholding the socialist road were of the utmost importance. While the principle of upholding the leadership of the Party is self-explanatory, the principle of upholding the socialist road seems vague. In Deng's view, predominance of public ownership is one of the two fundamental features of the socialist road..$^{12}$ When elaborating on his strategy of economic reform and development, Jiang Zemin (1997) also stated that 'being a socialist country, China must keep public ownership as the foundation of its socialist economic system'. To conclude, in the context of enterprise reforms, predominance of public ownership and leadership of the Party are the two fundamental socialist doctrines that have prevailed in China since Deng assumed power in $1978 .{ }^{13}$

These two fundamental socialist doctrines were constitutionalised in the 1982 PRC Constitution. Article 6 of the Constitution provides that 'the basis of the economic system is socialist public ownership of the means of production' and thus endorses the predominant position of public ownership of the means of production as a constitutional principle. The Party's leadership, together with Deng's three other cardinal principles, is enshrined in the Preamble. ${ }^{14}$ It can also be inferred from Article 1 of the Constitution, which reads, 'the PRC is a socialist country under the people's democratic dictatorship led by the working class and based on the alliance of workers and peasants', where the Party is supposedly representative of the working class (von Senger 2000). 
Few have doubted China's adherence to the fundamental socialist doctrines while reforming its SOE regime during the 1980s and early 1990s. However, the move to incorporation and ownership diversification since the mid 1990s (always by listing larger SOEs at stock exchanges and selling small or medium SOEs to private investors) has prompted some Western commentators to argue that China is heading toward mass privatisation (for example, Tam 1999) and an eventual abandonment of socialism.

This scenario is clearly not the intention of Chinese leaders and it seems unlikely to occur in the foreseeable future. In a pivotal policy document setting forth the orientation of enterprise reforms to 2010, the Decision on Major Issues Concerning the Reform and Development of State-Owned Enterprises ${ }_{1}^{15}$ the CPC reaffirms its guiding principles for future SOE reforms as upholding public ownership as the mainstay of the socialist market economy, and giving full play to the core role of Party organisations within enterprises. This position was recently reiterated by Jiang Zemin in his 2002 report to the Sixteenth CPC National Congress.

Having identified the fundamental socialist doctrines in the context of enterprise reforms, that is, predominance of public ownership of the means of production and the leadership of the Communist Party, I will now examine the extent to which, and the way in which, the CPC has shaped and influenced the development of the Chinese enterprise law.

\section{PREDOMINANCE OF PUBLIC OWNERSHIP OF THE MEANS OF PRODUCTION}

\section{9-78: SOEs subordinated to the state}

Largely due to Mao's philosophy of class struggle and, consequently, his hostility towards formal law, Chinese society under his rule was one in which legal nihilism prevailed. Apart from some basic laws enacted while heavily under the influence of the Soviet model of 'socialist legality' in the early 1950s, essentially no formal law existed. Having said that, however, the Measures of State-Run Industrial Enterprises Work (Draft) ${ }^{16}$ is, by its nature, a legal document regulating matters in relation to the governance of SOEs. The moderately comprehensive 1961 Measures, as will be illustrated below, exemplify that socialism could determine the contents of law and that the function of law was simply to render the highly abstract and conceptual ideology more concrete, substantial and operable.

Bluntly stipulating that 'the whole people ownership of state-run industrial enterprises must be firmly preserved and must not be violated' (Para. 1, Article 1), the foremost undertaking of the 1961 Measures was to safeguard public ownership of the means of production of SOEs. To this end, the state, pursuant to the then prevailing socialist ideology, not only owned the means of production on behalf of the people, but was also directly involved in the day-to-day management of SOEs. 
Indeed, direct management of SOEs by the state was instituted as the guiding principle, equal in importance to the principle of public ownership of the means of production. On behalf of the state, different levels of state agencies exercised excessive and rigid control over the daily management of SOEs, directing their production, controlling their pricing, and allocating their output. State-owned enterprises remitted any profits to the state, which, in turn, subsidised others' losses.

State-owned enterprises were subordinates or, in Chinese terms, 'appendages' to the state's administrative system and were subject to direct control by the state, as well as its mandatory plans. ${ }^{17} \mathrm{~A}$ SOE was supervised and directed chiefly by a 'higher authority' (1961 Measures, Para. 5, Article 4), which might be a ministry, provincial government or local government. ${ }^{18}$ The higher authority assigned the production plans to the SOEs in its control. These plans were given to the higher authority by an even higher level of authority. As one Western commentator vividly delineated, the state was one giant vertically-integrated productive firm. Ministries were divisions within the firm and enterprises were factories (Clarke 1992; Jiang Yiwei 1985). Stateowned enterprises typically had minimal decision-making powers over their production and business management — even their monthly production plans needed to be verified by their higher authorities (1961 Measures, Para. 1, Article 10).

Another manifestation of the subordinate position of SOEs was that Party Committee members and the management personnel of SOEs were appointed —and could be dismissed - by the higher authority. Indeed, SOE leadership was an integral part of the general governmental framework. Party Committee members and the management personnel of SOEs were entitled to political and economic treatment equivalent to cadres serving the Party and governmental agencies (Schipani and Junhai Liu 2002). They were held accountable to the higher authority, which took account of the fulfilment of the assigned production plans rather than the profitability of the SOE.

\section{8-82: excessive state control over SOEs remained}

State ownership of the means of production was reaffirmed and direct management by the state of SOEs remained the norm between 1978 and 1982. The Interim Regulations on State-Owned Industrial Enterprises ${ }^{19}$ made it clear that SOEs should conduct their production and business operations under the leadership of their higher authority (Article 5). The latter decided on all important issues ranging from production quota and plans to the direction of product development (Articles 23, 28, 62, 64). Moreover, the SOE director and other senior executives were appointed, dismissed and assessed by the higher authority. State-owned enterprises were not allowed to make decisions that contradicted those of the higher authority (Articles 63, 66).

\section{4-92: separating government from enterprises}

While state ownership of the means of production remained an unshakeable socialist doctrine, the Stalinist ideology of direct state management of SOEs was largely 
abandoned. An 'appropriate' separation of state administration from enterprise management was seen as necessary to improve efficiency.

Law was reformed to accommodate this ideological breakthrough. These reforms meant that SOEs were explicitly vested with significant managerial powers that they were not entitled to before 1984 . More significantly, law attempted to provide legal guarantees to safeguard these managerial powers. The Law on Industrial Enterprises Owned by the Whole People ${ }^{20}$ prohibited any state organ or unit from encroaching upon the managerial powers of SOEs (Article 58). The Regulations on Transforming Operational Management Mechanisms of Industrial Enterprises Owned by the Whole People ${ }^{21}$ further equipped SOEs with legal remedies in case any organ or individual was to interfere with their 'operational rights' ${ }^{22}$

In spite of these notable legal developments, the law still left a few crucial powers in the hands of the state and its agencies, that is, the higher authorities of SOEs. This was largely because the Chinese leaders aimed for an 'appropriate' rather than a complete separation between the government and enterprises. These crucial powers included issuing unified mandatory plans to SOEs; examining and approving important plans; and appointing or approving the nomination of the director and other senior executives. ${ }^{23}$ It was these powers that various governmental agencies took advantage of to justify their excessive interference with enterprise affairs. In practice, these powers severely undermined the effectiveness of the provisions that had granted SOEs remarkable managerial autonomy and attempted to safeguard their autonomy. It is therefore not surprising that a senior Chinese policy advisor maintained as late as 1997, that the utmost imperative mission of Chinese enterprise reforms was the separation of the government from enterprises (Liu Ji 1997).

\section{From 1993: the state as the company property owner and the majority shareholder}

Compared to pre-1993 national enterprise laws, the 1993 Company Law presents a key progression as it categorised an enterprise in accordance with its liabilities rather than the attributes of its owner (see Jiang Ping 1994). Moreover, the 1993 Company Law has universal application to all companies incorporated under it, ${ }^{24}$ and may have disallowed mandatory requirements in companies for state ownership of the means of production. These remarkable legal developments do not imply, however, that socialist ideology was abandoned in the 1993 Company Law. After all, the legislative backdrop of the 1993 Company Law was the corporatisation of SOEs (see also Art and Minkang Gu 1995), as evidenced by one of its legislative purposes, 'to promote the development of the socialist market economy' (Para. 5, Article 1). It is interesting to examine how the socialist ideology of predominance of state ownership of the means of production penetrates the 1993 Company Law and other related regulations.

To begin, the foremost (and conventional) issue to be addressed by company law is the ownership of the property and assets of a company. Given that pre-1993 
enterprise laws invariably mandated state ownership of SOEs' means of production, the 1993 Company Law represents an important step forward by incorporating the doctrine of corporate personality. Generally, a Chinese company has full entitlement to the so-called 'property right of legal person' created by the collective investment of its members. Despite the vagueness of the 'property right of legal person', ${ }^{25}$ this provision seems to conform to the essence of corporate personality in both common law $^{26}$ and civil law. ${ }^{27}$

However, Article 4(3) of the 1993 Company Law, which reads 'the ownership of state-owned assets in a company shall vest in the state', apparently contradicts the provision in Article 4(2) and casts doubt on whether the property of Chinese companies is genuinely distinct and separate from its members. ${ }^{28}$ Jurists have made efforts to interpret Article 4(3) to bring it in accordance with the doctrine of corporate personality (see, for example, Schipani and Junhai Liu 2002). These efforts, however, seem to be frustrated by the Provisional Regulations Concerning Supervision and Administration on State Assets in Enterprises ${ }^{29}$ in which 'state assets' are defined as 'the various forms of investments in enterprises by the state and rights and interests derived from such investments' (Article 3). This definition may well mean that the property of the company (in which the state has investments) is not separate from its member-the state- and that the state still retains ownership of the assets that it has invested in companies. Obviously, the extraordinary provision of Article 4(3) only has the effect of safeguarding the state's ownership of the company but may not necessarily lead to the dominant position of state ownership.

To secure the dominant position of state ownership in larger companies transformed from $\mathrm{SOEs}^{30}$ (which always take the joint-stock company corporate form), the state employed a legal strategy dividing shares of companies into three classes, namely, state-owned shares, legal person shares and social shares. Stateowned shares are typically held by the central and local governments (represented by local financial bureaus, state asset management companies or investment companies) and by the parent of the joint-stock company (typically an SOE or a wholly state-owned company). Legal person shares are shares held by such domestic institutions as industrial enterprises, non-bank financial institutions and technology and research institutes. State-owned shares and legal person shares are not tradable on the stock exchange. Social shares are shares held mostly by individuals (including enterprise employees) and by private institutions in some cases. Social shares of listed companies are generally tradable on stock exchanges. It is apparent by definition that such categorisation is based on the attributes of the shareholders, a practice already abandoned by the 1993 Company Law.

Official statistics show that each of the three classes account for about one-third of all outstanding shares of Chinese listed companies. ${ }^{31} \mathrm{It}$ is worth noting, however, that these statistics merely reflect the state's direct shareholding in listed companies, because they do not take the 'state-owned legal person shares' into account. This sub-category of legal person shares was introduced by the Tentative Measures 
Concerning Administration of State-Owned Equities of Joint Stock Companies. ${ }^{32}$ Legal person shares held by SOEs, state-owned institutions and other work units fall under this sub-category (1994 Tentative Measures, Article 2). State-owned shares and state-owned legal person shares, which are collectively referred to as stateowned equity in the 1994 Tentative Measures mandate (Article 2), must be in the position of control in joint stock companies (Article 3). This controlling position can be achieved by means of either an absolute control (over 50 per cent) over most of the listed company, or a relative control (30-50 per cent $)^{33}$ over the listed companies with a dispersed ownership structure (1994 Tentative Measures, Article 11).

In terms of the state-owned legal person shares, the direct and indirect shareholding of the state may account for a significantly higher proportion than one third of all outstanding shares in listed companies. A recent study has shown that the state is the majority shareholder in 53.6 per cent of Chinese listed companies and the state is in absolute control (control over 50 per cent of votes) of 24.3 per cent of Chinese listed companies (He Jun 1998). Another empirical observation is that the ultimate control of 84 per cent of Chinese listed companies is in fact in the hands of the state (Liu Shaojia et al. 2003).

The state's position as the majority shareholder, as has been observed above, calls for sufficient legal safeguards to protect the state's interests in the companies. One of the legal strategies utilised by the Chinese legislature is vesting an extraordinarily wide range of decision-making powers in the shareholder's general meeting under the 1993 Company Law (Article 38(103)), including managerial powers normally exerted by the board of directors in other jurisdictions. ${ }^{34}$ The roots of this corporate governance arrangement may be in the political governance philosophy expressed by the PRC Constitution (Schipani and Junhai Liu 2002). More practically, reserving vital decision-making powers exclusively to the shareholders' general meeting limits the managerial power of the board of directors, thus potentially helping to reduce the adverse effects of any abuse of powers or wrongdoing by directors. This legal strategy seemed desirable in light of the 'insider control' problems and the associated problem of managerial asset stripping. It may, however, cause inefficiency in decision-making, as one shareholders' general meeting per year would not be able to respond to the constantly changing market.

The government's overwhelming concerns about its own interests as the majority shareholder may also help to explain the 1993 Company Law's ignorance of minority protection and the failure to provide practicable legal mechanisms to protect the minority shareholders. This lack of minority protection has resulted in widespread malpractice in the Chinese stockmarket, whereby the majority shareholders abuse their position and exploit the public minority shareholders (see, for example, Anderson 2000; Wei Xinjiang 2002). 


\section{THE LEADERSHIP OF THE COMMUNIST PARTY}

\section{9-78: the Party taking the paramount leadership in SOEs}

To bring the ideology of the Party's leadership into practice, leadership of the unified Party at the factory level was the norm. The prevailing model was the 'director responsibility system under the leadership of the Party Committee', ${ }^{35}$ adopted at the Eighth National Congress of the CPC in 1956. The essence of the system was that the Party Committee played a monistic and all-encompassing role in SOE internal governance. All major enterprise decisions were to be made collectively by the Party Committee pursuant to the majority rule. ${ }^{36}$ The director was under the leadership of the Party Committee, acting as its executive. ${ }^{37}$ In practice, the Party Committee even deprived the directors of limited autonomy relating to enterprise production (Jiang 1985).

This unified Party leadership provided an institutional setting by which it penetrated into every corner of enterprise internal governance. Given that the Party Committee assumed all major decision-making powers, SOEs were in effect appendages not only of the state, but also of the ruling Party. Together with the higher authority, the Party Committee functioned to unify decision-making vertically, execution and control into one all-encompassing and centrally administered hierarchy (You 1998).

The collective leadership represented by the Party Committee induced inefficiency in decision-making. The director did not have the authority to make business policies, while the Party Committee, which had this authority, had little interest in issues of daily management and in any case did not possess relevant expertise. Moreover, unified leadership posed a problem of accountability, that is, of failing to identify who should take responsibility for any losses caused by a wrong decision. Indeed, Deng himself was aware of the accountability problem, saying that, 'nominal responsibility of the committee for decision-making means no responsibility, or nobody to be really responsible for decisions' (cited in Zhang Zanlun 1987:9).

\section{8-84: first attempt to apportion decision-making}

The director responsibility system under the leadership of the Party Committee was upheld in 1981 and 1983 (Article 1, 1981 Interim Regulations; Article 4, 1983 Interim Regulations). The director remained liable for decisions implemented by the Party Committee on enterprise production and administration. Nevertheless, attempts were made to reduce the influence of the Party Committee and to limit its direct involvement in daily management. The director was allowed to play a more vigorous role in two ways. First, the director was able to propose important matters to the 
Party Committee and the higher authority for their approval. These issues included business policies, long-term and annual plans and appointment of senior executives. Second, the director was granted full powers to decide on matters other than those mentioned above. In addition, a so-called 'factory-level meeting', comprising the deputy director and other senior executives, was accountable to the director rather than to the Party Committee. This bolstered the director's position. Theoretically, at least, when the director was given more decision-making power, a new decisionmaking hub slowly emerged. The state and the Party no longer monopolised the decision-making of SOEs (Zheng 1988).

These legal changes marked one of the first attempts ${ }^{38}$ to establish a sound and clear apportionment of decision-making between governance organs in the Chinese legal system, a classical question addressed by all modern company laws. They echoed the moderate pre-1984 ideological shifts, which attempted to equip SOEs with more managerial autonomy. However, these legal changes were destined to yield only marginal results due to policy indeterminacy (Tang Guodong 1987). The boundaries of decision-making of the state, the Party Committee and the director remained blurred and, as a result, past practicalities barely changed (Wang Baoshu and Cui Qingzhi 1984), although the general trend pointed to weakened state and Party roles in SOEs.

\section{4-92: power sharing between the Party Committee and the management}

The director responsibility system (not subject to the Party Committee's leadership) was first endorsed in the 1984 Decisions. A circular jointly issued by the CPC Central Committee and the State Council in 1986 overtly claimed that

[t]he director of an industrial enterprise owned by the whole people is the head of the enterprise and the representative of the 'enterprise legal person', assuming the overall responsibility for the enterprise, occupying the central position and playing the central role. ${ }^{39}$

This delineation of the director's role was partly reproduced in the 1988 Enterprise Law (Article 45). Indeed, the three Regulations issued in 1986 and the 1988 Enterprise Law all unambiguously provided for the director responsibility system..$^{40}$ The director was empowered to decide on important matters for the $\mathrm{SOE}_{,}^{41}$ with the assistance of a management committee acting in an advisory manner.

These provisions marked the end of the three decades of the Party Committee command system practicalities. The dominant role of the Party Committee in everyday factory life was greatly curtailed. The Party Committee was intentionally kept out of the enterprise management ${ }^{42}$ and its role was confined to conducting 'ideological education' and 'guaranteeing and supervising the implementation of guidelines and policies of the Party and the state'. ${ }^{43}$ It is a striking feature of the pre1993 enterprise law that the Party organs were increasingly marginalised in enterprise production and administration.

This legal move, which had the prima facie effect of undermining the Party's leading role in SOEs, seems to be inconsistent with the ideological doctrine of the 
Party's leadership. Indeed, it again manifests the Chinese leadership's pragmatic stance towards the interactions of enterprise efficiency and socialist ideology. It was indisputable that most Party cadres (including the Party secretary, the de facto controller of the Party Committee in SOEs) were laymen to enterprise management. Stringently adhering to the Party Committee unified leadership system at the factory level inevitably led to inefficiency. It was thus a more efficient allocation of decisionmaking to have the Party Committee focus on the areas in which it had expertise, ${ }^{44}$ leaving the business operations to the director. A new legal regime was thus created at the micro factory level in which the Party Committee was accorded a core role in leading the factories' political life, paralleling the management's central position in leading the factories' economic life (You Ji 1998). In the meantime, the Party's leadership still manifested at a more macro level by formulating economic and enterprise reform policies and guidelines and by appointing and, where necessary, removing the director through the higher authority.

\section{From 1993: the Party Committee returns?}

The 1993 Company Law appears to have gone further to make sure that the Party Committee was not involved in enterprise management. Article 17 provides that the activities of grassroots organisations of the Party within companies (which always take the form of Party Committee) must abide by the Party's Constitution. On the face of it, this provision is one that applies merely to internal affairs of the Party Committee. Apart from this provision, the 1993 Company Law says nothing more about the Party Committee's role in the company. ${ }^{45}$ Considering the connection with the legislative trend of phasing out the Party Committee's involvement in enterprise management, it appears that the Party Committee will play an increasingly insubstantial role, if any, in companies.

However, an alternative interpretation of Article 17 also appears. First, Article 17 may provide a solid justification for the Party Committee to exist and operate in the company. More significantly, by providing for the exclusive application of the Party's Constitution to the Party Committee in the company, it may in effect preclude the application of the 1993 Company Law to the Party Committee and give the Party's Constitution implicit statutory authority to supplement the 1993 Company Law. This interpretation of Article 17 seems more constructive if one examines the Party's Constitution.

The Party's Constitution confers on the Party Committee in the company not only the power of 'guaranteeing and supervision', which it was entitled to under the previous enterprise laws, but also the power to participate in company decisionmaking, which previous legislation attempted to phase out. Article 32 of the Party's Constitution ${ }^{46}$ reads

The Party's grassroots organisation acts as the political nucleus and works for the operation of the enterprise. [It] guarantees and supervises the implementation of the principles and policies of the Party and the state in its own enterprise and backs the shareholders' general meeting, the board of directors, the supervisory board and the manager (factory director) 
in the exercise of their functions and powers according to law. [It] relies wholeheartedly on the workers, supports the work of the workers' congress and participates in the decisionmaking of major matters in the enterprise...[emphasis added]

If the Party's Constitution is but a set of rules applicable to the Party Committee and has no binding legal effect on the company, it makes one wonder what Article 32 was supposed to achieve. Therefore, it is more sensible to understand Article 17 as one that has the legal effect of allowing the Party's Constitution to supplement the 1993 Company Law in many aspects. In this sense, the 1993 Company Law allows the possibility of the Party Committee in the company becoming a governance organ, if the Party's Constitution so provides.

The way in which the Party Committee may act as a governance organ, as noted, is determined by the Party's Constitution. Being a set of general norms, the Party's Constitution itself is silent in this regard. It is the fundamental principle of the Party's Constitution, however, that the lower Party organ is subordinate to its superiors and must comply unconditionally with decisions, resolutions, instructions and directives from superiors. ${ }^{47}$ To be sure, these decisions, resolutions, instructions and directives are not normally deemed legally binding. Article 17 does not give them legal authority, but the aforementioned principle of the Party's Constitution lends them authority and elevates them to become legally binding on the Party Committee in the company and on the company itself. It follows that the Party Committee may lawfully participate in corporate governance in the way that decisions, resolutions, instructions and directives from its superiors (in particular, the CPC Central Committee) prescribe.

A momentous CPC Central Committee Circular issued in $1997^{48}$, dealing with companies transformed from SOEs, covers the major issues relating to the extent and ways that the Party Committee may act as a governance organ in these companies. It clarifies that the 'major matters in the enterprise' described by Article 32 of the Party's Constitution refer to all matters discussed and decided by the shareholders' general meeting and the board of directors. Decision-making by the board of directors on these matters is closely scrutinised and supervised by the Party Committee. To elaborate, the board of directors must solicit and show respect to the Party Committee's opinions on these matters before making its own decisions. They then notify the Party Committee of the implementation of the decisions. The Party Committee may require the board of directors to rectify the decisions if it finds they contradict Party policies, guidelines and laws. Second, the Party Committee plays an active and vital part in nominating and appointing medium-level managers, a power that the 1993 Company Law has reserved exclusively to the general manager. ${ }^{49}$ More significantly, Party cadres are encouraged to be directly involved in the day-to-day management of the company, and the Party secretary may serve concurrently as the chairman of the board of directors. Other members of the Party Committee may become members of the board of directors, the supervisory board and the senior management, in accordance with law, and vice versa. 
These measures exemplify the Party's intention to take the leading role in, and steer the orientation of, the process of corporatising SOEs (1997 Party Central Committee Circular), by maintaining the Party's leadership at the company level and directly or indirectly participating in corporate governance. Realistically, these measures are useful in confining the imprecise - but in practice extensive-decisionmaking power of the Party Committee and, consequently, in aiding the full functioning of new governance organs. ${ }^{50}$ Nevertheless, there are inconsistencies with the 1993 Company Law. For example, the decision-making power of the Party Committee overlaps those of the other governance organs, blurring the boundaries of decision-making of various governance organs prescribed by the 1993 Company Law. Moreover, it is problematic that the directors' legal duties and liabilities are inapplicable to the Party Committee and its members, which virtually means the Party Committee is in effect a governance organ with remarkable powers but little accountability. These drawbacks add difficulties to the attempts of reforming the already defective Chinese corporate governance law regime. Building up a sound system of corporate governance in line with internationally recognised standards in China is also made very difficult.

\section{WHITHER REFORM? SOCIALISM AND THE FUTURE OF CHINESE ENTERPRISE LAW}

The efficiency-oriented Chinese enterprise reforms have been the key component of China's transition from a traditional planned economy to a socialist market-oriented economy. In this process, an impressive body of enterprise law has emerged, with the recent legislation increasingly embracing corporate forms and business practices in the Western market economies in a bid to improve efficiency. ${ }^{51}$ However, the development of the Chinese enterprise law regime has involved socialist ideology so extensively that one Western commentator once disappointedly concluded that 'the state is merely changing the form, but not the substance of economic relationships' (Howson 1997:172-3). This disappointment is inevitable, given that Chinese enterprise reforms are simply a means to bolster socialism and its economic foundation and that law has long been used as an instrument to implement the Party's enterprise reform policies. The orthodox ideology is, no matter how far enterprise and legal reforms progress, the bottom line will always be there-socialism with Chinese characteristics must be adhered to.

In spite of socialist orthodoxy, the fate of Chinese enterprise law may change owing to a number of far-reaching recent developments. First and foremost, the interpretation of the nature of 'socialism with Chinese characteristics' may shift. As noted, the Chinese leaders have been pragmatic in adjusting the interpretations of socialist ideology to accommodate economic development. The incorporation of the 'three represents' thought ${ }^{52}$ into the Party's Constitution in 2002 and the promulgation of the CPC Central Committee's Decisions on Perfecting the Socialist 
Market Economy in 2003 may well signal such a shift. Second, China amended its Constitution in 1999 to endorse the principle of 'ruling the country in accordance with law'. Although it is unlikely that the Chinese leadership would favour the liberal democratic version of rule of law (see Peerenboom 1999, 2002), the constitutionalisation of the rule-of-law principle may help to curtail the instrumental use of law in China. Finally, China's commitments under the World Trade Organisation (WTO) expose Chinese enterprises to increasingly fierce international competition, adding to the urgent need for reforms of the defective Chinese enterprise law regime to build a sound corporate governance system and provide sufficient protection to investors..$^{53}$

An amendment of the 1993 Company Law is reportedly part of the NPC legislative blueprint in the future. This scheduled amendment will present us with a new opportunity to observe the intractable interactions of socialist ideology, economic efficiency and legal instrumentalism in socialist China.

\section{ACKNOWLEDGMENT}

The author would like to thank Michael Palmer for helpful comments. The usual disclaimer applies.

\section{NOTES}

1 Or sheng chan zi liao, which refers to the facilities and resources for producing goods.

2 See Lubman (1999). Legal instrumentalism and the relationship between policy and law in China will be dealt with in more detail later.

3 Those who took a hostile attitude towards the newly established communist People's Republic of China, in particular, the United States and its then allies.

4 Although the Stalinist line of economic development strategy was abandoned, the Soviet pattern of command economy and enterprise management remained and had dominated China for several decades (see Howe et al. 2003).

5 They were the 1957-61 decentralisation and Great Leap Forward, and in 1962-65 the period of readjustment. For a detailed account, see Riskin (1987) and Gao and Yang (1999).

6 Deng Xiaoping, the late paramount Chinese leader, acknowledged, 'we started the reform first in the rural areas. It was only after it had produced results there that we had the courage to launch it in the cities. In fact, the urban reform is a reform of the economic structure as a whole and is very risky' (Deng Xiaoping 1994:134).

7 Decisions of the CPC Central Committee on Some Issues Concerning the Establishment of a Socialist Market Economy System, adopted by the Third Plenary Session of the CPC Fourteenth National Congress on 14 November 1993 (hereinafter, '1993 Decisions').

8 For an illustration of the debate concerning the meaning of the 'modern enterprise system', see Wang Baoshu (2002).

9 The Company Law of the People's Republic of China (promulgated on 25 December 1993, and in effect on 1 July 1994. Hereinafter the '1993 Company Law'). See Yongqing Zhao (1996); Jiang Ping (1994).

10 The Securities Law of the People's Republic of China (promulgated on 29 December 1998, and in effect on 1 July 1999. Hereinafter the '1998 Securities Law').

11 See Tenev and Chunlin Zhang (2002:1). Official statistics show that by 2002, 442 companies transformed from larger SOEs have become listed companies and that more than 80 per cent of small-sized county-level SOEs and 60 per cent small-sized city-level SOEs have been sold to private investors. See also http://www.sasac.gov.cn/ldjh/ldjh_0068.htm. 
12 The other feature is common prosperity, which is related to the wealth distribution system and not the direct concern of this chapter. See Deng Xiaoping (1994d).

13 Glendon, Gordon and Osakwe's (1985) comparative work on the socialist legal tradition reached a similar conclusion. Of a number of elements, an uncompromising recognition of the supreme leadership of the Communist Party and state ownership of the dominant means of production and distribution were identified as two of the elements of the ideology of the socialist legal system.

14 Legal scholars have, however, expressed different views on the exact force of the Preamble (Chen 1998).

15 Adopted at the Fourth Plenum of the Fifteenth CPC Central Committee on 22 September 1999.

16 Issued by the CPC Central Committee in 1961 and implemented on a trial basis nationally (hereinafter '1961 Measures').

17 Para. 1, Article 4 of the 1961 Measures reads, 'unified leadership, hierarchical governance, is the principle of the state's administration on state-run industrial enterprises ...'.

18 The assignation of the higher authority depends largely on the scale of the SOE in question and may change over time. The larger firms are likely to be held accountable to an appropriate ministry. Medium and small-sized firms are supervised at a level appropriate to the market they serve. See Hay et al. (1994).

19 Issued by the State Council on 1 April 1983. Hereinafter the '1983 Interim Regulations'.

20 Adopted by the Seventh NPC on 13 April 1988 and came into force on 1 August 1988. Hereinafter, the '1988 Enterprise Law'.

${ }^{21}$ Issued by the State Council and came into force on 23 July 1992. Hereinafter, the '1992 Regulations'.

2 The 1992 Regulations, Article 22. The SOEs may choose to appeal or inform the government or its competent department, or go straight to the court to litigate against the organ or individual.

23 The 1988 Enterprise Law, Article 55; Regulations on the Work of Director of Industrial Enterprises Owned by the Whole People (issued by the CPC Central Committee and the State Council on 15 September 1986 and became effective on 1 October 1988. Hereinafter the 1986 Director Regulations), Article 9.

24 Indeed, the State Council's 1992 draft of company law, which proposed to apply merely to state-owned companies, failed to pass through in the NPC. See Bian Yaowu and Li Fei (1994).

25 Keith and Zhiqiu Lin (2001) present an excellent elaboration of jurisprudential discourse of the 'property right of legal person' in China.

26 In English law, the fundamental attribute of corporate personality is that a company is an entity separate and distinct from its members, and the property of the company is clearly distinguished from that of its members (Davies 2003; Sealy 2001).

27 The core element of legal personality in civil law is that the firm owns its own assets, which are distinct from the property of other persons (Kraakman et al. 2004).

28 Kong Xiangjun (1994), when reviewing Article 4 of the 1993 Company Law, sharply argued the state has ownership over the state-owned assets.

29 Issued by the State Council on 13 May 2003. Hereinafter, 2003 Provisional Regulations on State Assets.

30 Normally, large or medium-sized SOEs were corporatised.

31 By the end of 1998, state-owned shares totalled 86.6 billion shares, 34.25 per cent of the total equity of Chinese listed companies; legal person shares totalled 71.6 billion shares, 28.35 per cent of the total equity; tradable shares totalled 86.2 billion shares, 34.11 per cent of the total equity (among which A shares 24.06 per cent, B shares 5.30 per cent, $\mathrm{H}$ shares 4.75 per cent). Statistics available on the China Securities Regulatory Commission (CSRC) website: http:// www.csrc.gov.cn/CSRCSite/eng/esmintr.htm.

32 Co-issued by State Administration of State-Owned Assets and State Commission for Economic Restructuring on 3 November 1994. Hereinafter, the '1994 Tentative Measures'.

33 Notably, La Porta et al. (1999) define that a corporation has a controlling shareholder if this shareholder's direct and indirect voting rights in the firm exceed 20 per cent.

34 For example, Article 70 of Table A, 1985 UK Companies Act, provides that '... the business of the company shall be managed by the directors who may exercise all the powers of the company'. In practice, the shareholders of larger companies in the United Kingdom, United States and Germany generally delegate decision-making extensively to the board (Davies 2003). 
35 Para 2, Article 6 of the 1961 Measures stipulates that the director responsibility system under the leadership of Party Committee is the fundamental enterprise governance system.

36 The 1961 Measures, Para 3, Article 6; Paras 1 and 3, Article 62.

37 The 1961 Measures, Para 3, Article 55; Paras 2 and 3, Article 54.

38 The 1979 Equity Joint Venture Law also dealt with the question.

39 Article 1, The Supplementary Circular of the CPC Central Committee and the State Council Concerning Carefully Carrying Out and Implementing the Three Regulations on Industrial Enterprises Owned by the Whole People (issued 11 November 1986).

40 Article 1, 1986 Director Regulations; Article 2, The Regulations on the Work of Grass-Root Organizations of the CPC of Industrial Enterprises Owned by the Whole People (jointly issued by the CPC Central Committee and the State Council on 15 September 1986 and became effective on 1 October 1988. Hereinafter the '1986 CPC Grass-Root Regulations'); Article 2, The Regulations on the Work of Workers' Congress of Industrial Enterprises Owned by the Whole People (jointly issued by the CPC Central Committee and the State Council on 15 September 1986, effective 1 October 1988. Hereinafter '1986 Workers' Congress Regulations'); Article 7, The 1988 Enterprise Law.

${ }^{41}$ Article 47, 1988 Enterprise Law; Article 10 and 11, 1986 Director Regulations.

42 Indeed, to ensure the independence and integrity of managerial autonomy of the director, the Party Committee secretary was generally not allowed concurrently to assume the position of director under 1986 CPC Grass-Root Regulations.

43 Article 8, The 1988 Enterprise Law.

4. Namely, 'ideological education' and 'guaranteeing and supervising the implementation of guidelines and policies of the Party and the state'.

45 In fact, this provision did not even appear in the final draft of the 1993 Company Law. It was the NPC Law Committee that added the provision during their deliberation of the final draft. Some of its members felt it necessary to make some provisions in respect of the activities of the Party in companies. See Xiang Chunyi's Report of Amendment Opinions Concerning the Company Law (Revised Draft) and the Decision to Amend the Accounting Law to the NPC on 29 December 1993.

46 Amended and adopted at the CPC Sixteenth National Congress on 14 November 2002.

47 The 2002 Party Constitution, Article 10(1).

48 The Circular Concerning Further Strengthening and Improving the Party's Construction Work in State-Owned Enterprises, issued by the CPC Central Committee on 24 January 1997. Hereinafter the '1997 Party Central Committee Circular'.

49 The 1993 Company Law, Articles 50(7) and 119(7).

50 Tenev and Chunlin Zhang (2002) observed that the incremental approach to enterprise reforms resulted in new governance organs emerging alongside the old ones, which are groping their way to becoming functional.

51 One example is the introduction of the role of independent directors into Chinese listed companies in 2002, whereas the Chinese board structure is a two-tier one with a supervisory board.

52 This calls for the CPC to represent the development trend of China's advanced social productive forces, the orientation of China's advanced culture, and the fundamental interests of the overwhelming majority of the people of China.

53 Empirical studies have shown that capital tends to flow to the financial markets with strong investor protection and effective corporate governance. See, for example, La Porta et al. (2000).

\section{REFERENCES}

Anderson, D.M., 2000. 'Taking stock in China: company disclosure and information in China's stock markets', Georgetown Law Journal, 88(6):1919-53.

Art, R.C. and Minkang Gu, 1995. 'China incorporated: the first Corporation Law of the People's Republic of China', Yale Journal of International Law, 20(2):273-308.

Bian Yaowu and Li Fei (eds), 1994. Theory and Practice of Company Law [Gongsifa de Lilun yu Shiwu], China Commerce Press, Beijing. 
Butler, W.E., 1983. The Legal System of the Chinese Soviet Republic 1931-34, Transnational Publishers Inc, Dobbs Ferry, New York.

Chai, J., 1997. China: transition to a market economy, Oxford University Press, New York.

Chen, A.H., 1998. An Introduction to the Legal System of the People's Republic of China, Butterworths (Asia), Singapore, Malaysia and Hong Kong.

Chen, A.H.Y., 2000. 'Socialist law, civil law, common law, and the classification of contemporary Chinese law', in J.M. Otto, M.V. Polak, Jianfu Chen and Juwen Li (eds), Law-Making in the People's Republic of China, Kluwer Law International, The Hague:55-64.

Chen Jianfu, 1999. Chinese Law: towards an understanding of Chinese law, its nature, and development, Kluwer Law International, The Hague and Boston.

- 2000. 'Coming full circle: law-making in the PRC from a historical perspective', in J.M. Otto, M.V. Polak, Jianfu Chen and Juwen Li (eds), Law-Making in the People's Republic of China, Kluwer Law International, The Hague:19-40.

Clarke, D.C., 1992. 'Regulation and its discontents: understanding economic law in China', Stanford Journal of International Law, 28:282-322.

Coffee, J.C., 1998. 'Inventing a corporate monitor for transitional economies: the uncertain lessons from the Czech and Polish experiences', in K. Hopt, H. Kanda, M.J. Roe, E. Wymeersch and S. Prigge (eds), Comparative Corporate Governance: the state of the art and emerging research, Oxford University Press, New York:67-138.

CPC Central Committee, 1984. Decisions of the CPC Central Committee on the Economic Structure Reform, adopted by the Third Plenary Session of the CPC Twelfth National Congress, Beijing, 20 October 1984.

Deng Xiaoping, 1994. Selected Works of Deng Xiaoping, Volume 3, Foreign Language Press, Beijing.

—_, 1995. Selected Works of Deng Xiaoping, Volume 2, Second edition, Foreign Language Press, Beijing.

Davies, P.L., 2003. Gower and Davies' Principles of Modern Company Law, Sweet and Maxwell, London.

Epstein, E.J., 1994. 'Law and legitimation in Post-Mao China', in P. Potter (ed.), Domestic Law Reforms in Post-Mao China, M. E. Sharpe, New York and London:1955.

Gao Shangquan and Yang Qixian (eds), 1999. China's State-Owned Enterprise Reform [Zhongguo Guoyou Qiye Gaige], Jinan Press, Jinan.

Glendon, M.A., Gordon, M.W., and Osakwe, C., 1985. Comparative Legal Traditions: text, materials and cases, West Publishing Co, St. Paul, Minnesota.

Hay, D., Morris, D., Liu, G. and Shujie Yao, 1994. Economic Reform and State-Owned Enterprises in China, 1979-1987, Oxford University Press, New York.

He Jun, 1998. 'An empirical analysis of corporate governance of the listed companies [Shangshi Gongsi Zhili Jiegou de Shizheng Fenxi]', Economic Research Journal [Jingji Yanjiu], 5:50-57. 
Howe, C., Kueh, Y.Y. and Ash, R., (eds), 2003. China's Economic Reform: a study with documents, RoutledgeCurzon, London.

Howson, N.C., 1997. 'China's company law: one step forward, two steps back? A modest complaint', Columbia Journal of Asian Law, 11(1):127-73.

Jiang Ping, 1994. 'The modern enterprise system established under the Company Law [Gongsi Fa suo Jianli de Xiandai Qiye Falu Zhidu]', Study and Exploration of Theories [Lilun Xuexi yu Tansuo], 3:2

Jiang Yiwei, 1985. 'On the leadership mechanism of Socialist enterprises [Lun Shehui Zhuyi Qiye de Lingdao Tizhi]', in Jiang Yiwei (eds), Discussions on Certain Issues of Economic System Reform and Enterprise Management [Jingji Tizhi Gaige he Qiye Guanli Ruogan Wenti de Taolun], Shanghai People's Press, Shanghai:16-40.

Jiang Zemin, 1997. Hold High the Great Banner of Deng Xiaoping Theory for an Allround Advancement of the Cause of Building Socialism with Chinese Characteristics to the 21st Century, Report to the CPC Fifteenth National Congress, Beijing.

, 2002. Build a Well-off Society in an All-Round Way and Create a New Situation in Building Socialism with Chinese Characteristics, Report to the CPC Sixteenth National Congress, Beijing.

Keith, R.C. and Zhiqiu Lin, 2001. Law and Justice in China's New Marketplace, Palgrave, Basingstoke.

Kong Xiangjun, 1994. 'On Ownership Structure of Modern Companies: also reviewing provisions on company ownership in the Company Law of our country [Lun Gongsi Chanquan de Jiegou: Jianping Woguo Gongsifa dui Gongsi Chanquan de Guiding]', Tribune of Political Science and Law [Zhengfa Luntan], 4:31-35.

Kraakman, R., Davies, P., Hausmann, H., Hertig, G., Hopt, K.J., Kanda, H. and Rock, E.B., 2004. The Anatomy of Corporate Law: a comparative and functional approach, Oxford University Press, New York.

Lin Zhijun, 2001. 'Recent development of tax system reforms in China: challenges and responses', The International Tax Journal, 27(1):90-103.

Liu Ji, 1997. 'Separating government and enterprises', in Guanzhong Wen and Dianqing Xu (eds), The Reformability of China's State Sector, World Scientific Publishing Co., Singapore:16-36.

Liu Shaojia et al., 2003. 'The theory of ultimate ownership, ownership structure and firm's performance [Zhongji Chanquan Lun, Guquan Jiegou yu Gongsi Jixiao]', Economic Research Journal [Jingji Yanjiu], 4:51-62.

Lo, Carlos Wing-Hung, 1997. 'Socialist legal theory in Deng Xiaoping's China', Columbia Journal of Asian Law, 11(2):469-86.

Lubman, S., 1999. Bird in a Cage: legal reform in China after Mao, Stanford University Press, Stanford.

Peerenboom, R., 1999. 'Ruling the country in accordance with law: reflections on the rule and role of law in contemporary China', Cultural Dynamics, 11(3):315-52. 
- 2002. China's Long March Toward Rule of Law, Cambridge University Press, Cambridge.

La Porta, R., Lopez-de-Silanes, F. and Shleifer, A., 1999. 'Corporate ownership around the world', Journal of Finance, 54(2):471-517.

- and Vishny, R., 2000. 'Investor protection and corporate governance', Journal of Financial Economics, 58(1):3-27.

Qi Duojun, 2003. Studies on Legal Problems Concerning Reorganising State-Owned Enterprises by Incorporatisation [Guoyou Qiye Gufen Gongsi Gaizu Falu Wenti Yanjiu], China Fangzheng Press, Beijing.

Qian, Andrew Xuefeng, 1993. 'Riding two horses: corporatizing enterprises and the emerging securities regulatory regime in China', UCLA Pacific Basin Law Journal, 12:62-97.

Riskin, C., 1987. China's Political Economy: the quest for development since 1949, Oxford University Press, Oxford.

Schipani, C.A. and Junhai Liu, 2002. 'Corporate governance in China: then and now', Columbia Business Law Review, 1:1-69.

Sealy, L.S., 2001. Cases and Materials in Company Law, Seventh edition, Butterworths, London.

von Senger, H., 2000. 'Ideology and law making', in J.M. Otto, M.V. Polak, Jianfu Chen and Juwen Li (eds), Law Making in the People's Republic of China, Kluwer Law International, The Hague:41-54.

Stiglitz, J.E., 1999. Whither Reform? Ten years of the transition, Keynote Address to the World Bank Annual Bank Conference on Development Economics, Washington, DC, 28-30 April. Available online at http:/ /www.worldbank.org/ research/abcde/pdfs/stiglitz.pdf.

Tam, On Kit, 1999. The Development of Corporate Governance in China, Edward Elgar, Cheltenham.

Tang Guodong, 1987. An Introduction to Industrial Enterprise Law, China's People's University Press, Beijing.

Tenev, S. and Chunlin Zhang, 2002. Corporate Governance and Enterprise Reform in China: building the institutions of modern markets, World Bank and International Finance Corporation, Washington, DC.

Wang Baoshu, 2002. Legal System of Enterprise Systems [Xiandai Qiye Falu Zhidu], Standing Committee Legal Lecture to the Twentieth National Party Congress, Beijing, 31 May. Available online at http:/ / www.npcnews.com.cn/gb/special/ class000000033/1/hwz210144.htm.

Wang Baoshu and Cui Qingzhi, 1984. 'On the legal status of directors of state-run enterprises [Lun Guoying Qiye Changzhang de Falu Diwei]', Legal Research [Faxue Yanjiu], 1:28-35.

Wang, Wallace Wen-Yeu, 1992. 'Reforming state enterprises in China: the case for redefining enterprise operating rights', Journal of Chinese Law, 6(2):89-136. 
Wei, Xinjiang, 2002. 'People's Republic of China: the legal features of Chinese capital markets in the light of the Zhengzhou Baiwen case', Company Lawyer, 23(3):100-4.

Xiang Chunyi, 1993. Report of Amendment Opinions Concerning the Company Law (Revised Draft) and the Decision to Amend the Accounting Law (Legislative Report to the NPC)

Xin Chunyun, 1999. Chinese Legal System and Current Legal Reform, The Law Press, Beijing.

You Ji, 1998. China's Enterprise Reform: changing state/society relations after Mao, Routledge, London and New York.

Zhang Zanlun, 1987. The Director Responsibility System [Changzhang Fuzezhi], Economic Press, Beijing.

Zhang Youyu and Wang Shuwen (eds), 1989. Forty Years of the PRC's Legal Science [Zhongguo Faxue Sishi Nian], Shanghai People's Press, Shanghai.

Zhao Yongqing, 1996. 'The Company Law of China', Indiana International E Comparative Law Review, 6:461-92.

Zhao Ziyang, 1987. 'Advance along the road of Socialism with Chinese Characteristics-Report delivered at the Thirteenth National Congress of the $\mathrm{CPC}^{\prime}$, in Documents of the Thirteen National Congress of the Communist Party of China, Foreign Language Press, Beijing.

Zheng, H.R., 1988. China's Civil and Commercial Law, Butterworth \& Co (Asia), Singapore. 